Article

\title{
Energy Storage Behavior of Lithium-Ion Conducting poly(vinyl alcohol) (PVA): Chitosan(CS)-Based Polymer Blend Electrolyte Membranes: Preparation, Equivalent Circuit Modeling, Ion Transport Parameters, and Dielectric Properties
}

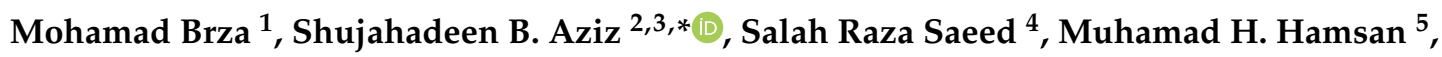 \\ Siti Rohana Majid ${ }^{6}$, Rebar T. Abdulwahid ${ }^{2,7}$ (), Mohd F. Z. Kadir ${ }^{5}$ and Ranjdar M. Abdullah ${ }^{2}$ \\ 1 Manufacturing and Materials Engineering Department, Faculty of Engineering, International Islamic \\ University of Malaysia, Kuala Lumpur 50603, Malaysia; mohamad.brza@gmail.com \\ 2 Hameed Majid Advanced Polymeric Materials Research Laboratory, Physics Department, College of Science, \\ University of Sulaimani, Qlyasan Street, Sulaimani 46001, Iraq; rebar.abdulwahid@univsul.edu.iq (R.T.A.); \\ ranjdar.abdullah@univsul.edu.iq (R.M.A.) \\ 3 Department of Civil Engineering, College of Engineering, Komar University of Science and Technology, \\ Sulaimani 46001, Iraq \\ 4 Charmo Research Center, Charmo University, Peshawa Street, Chamchamal 46023, Iraq; \\ salah.saeed@charmouniversity.org \\ 5 Centre for Foundation Studies in Science, University of Malaya, Kuala Lumpur 50603, Malaysia; \\ hafizhamsan93@gmail.com (M.H.H.); mfzkadir@um.edu.my (M.F.Z.K.) \\ 6 Centre for Ionics University of Malaya, Department of Physics, Faculty of Science, University of Malaya, \\ Kuala Lumpur 50603, Malaysia; shana@um.edu.my \\ 7 Department of Physics, College of Education, Old Campus, University of Sulaimani, \\ Kurdistan Regional Government, Sulaimani 46001, Iraq \\ * Correspondence: shujahadeenaziz@gmail.com
}

Received: 7 November 2020; Accepted: 26 November 2020; Published: 30 November 2020

\begin{abstract}
Plasticized lithium-ion-based-conducting polymer blend electrolytes based on poly(vinyl alcohol) (PVA):chitosan (CS) polymer was prepared using a solution cast technique. The conductivity of the polymer electrolyte system was found to be $8.457 \times 10^{-4} \mathrm{~S} / \mathrm{cm}$, a critical factor for electrochemical device applications. It is indicated that the number density $(n)$, diffusion coefficient $(D)$, and mobility $(\mu)$ of ions are increased with the concentration of glycerol. High values of dielectric constant and dielectric loss were observed at low frequency region. A correlation was found between the dielectric constant and DC conductivity. The achieved transference number of ions $\left(t_{\text {ion }}\right)$ and electrons $\left(t_{e}\right)$ for the highest conducting plasticized sample were determined to be 0.989 and 0.011 , respectively. The electrochemical stability for the highest conducting sample was $1.94 \mathrm{~V}$, indicated by linear sweep voltammetry (LSV). The cyclic voltammetry (CV) response displayed no redox reaction peaks through its entire potential range. Through the constructing electric double-layer capacitor, the energy storage capacity of the highest conducting sample was investigated. All decisive parameters of the EDLC were determined. At the first cycle, the specific capacitance, internal resistance, energy density, and power density were found to be $130 \mathrm{~F} / \mathrm{g}, 80 \Omega, 14.5 \mathrm{Wh} / \mathrm{kg}$, and $1100 \mathrm{~W} / \mathrm{kg}$, respectively.
\end{abstract}

Keywords: PVA:CS polymer blends; electrical equivalent circuit; impedance study; ion transport properties; dielectric properties; energy storage study 


\section{Introduction}

The use of environmentally friendly electrolytes is one of the hot topics in secondary lithium batteries studies. Solid polymer electrolytes (SPEs) have been under intensive study despite being familiarized with these electrolytes 40 years ago [1]. Verma et al. [2] fabricated nanocomposite polymer electrolyte of $95(70 \mathrm{PEO}: 30 \mathrm{AgI}): 5 \mathrm{SiO}_{2}$ with the high conductivity of $2.5 \times 10^{-3} \mathrm{~S} / \mathrm{cm}$. The authors indicated that the polymer electrolyte is suitable for solid state capacitor applications due to the conductivity enhancement and improvement in amorphous structure.

SPEs are composed of polymer hosts enriched with polar groups where salt is dissolved, showing desirable properties [3]—such as light weight, high flexibility factor, and lack of leakage [4,5]. It is also worth mentioning that these polymer electrolytes are superior over inorganic solids in terms of flexibility [6,7]. The inorganic solid electrolyte is appropriate for rigid battery design, as it has higher mechanical strength, better chemical/thermal stabilities, and shows a clear conductivity advantage over a wide range of temperatures. Nevertheless, the sulfide-based inorganic electrolyte chemical stability has to be more developed; whereas, for NASICON (NA super ion conductor)-based inorganic electrolyte, its wetting with sodium metal must be improved, so as to enhance the cycling life and energy density in the resultant sodium-ion battery with metallic sodium as anode [8]. Natural SPEs-mainly starch, cellulose, chitosan (CS), carrageenan, and agarose-have recently drawn significant attention. This is because of their potential uses in electrochemical devices, such as electrochromic devices, high energy density batteries, sensors, EDLC, and fuel cells [9-11]. These natural polymers are featured by biodegradability, environmental friendliness, and easy handling during preparation [12,13]. CS is the second abundant natural biopolymer after cellulose [14,15]. It is obtained from the extraction process where shrimp waste has been used as a source enriched in CS [16,17]. CS is a polycationic polymer that within each monomer unit contains one amino and two hydroxyl groups [18]. Natural polymers have been focused on their high biocompatibility, biodegradability, low toxicity, and cost-effectiveness [19,20]. A qualified candidate to be used as a host polymer in the electrolyte preparation is the semi-crystalline poly (vinyl alcohol) (PVA). Nowadays, PVA has been used in several energy devices, including direct methanol fuel cells, Zn-air batteries and rechargeable $\mathrm{Ni}-\mathrm{MH}$ batteries [21-23]. PVA provides exceptional properties, for instance, high dielectric strength, plausible charge-storage capacity, and film-forming capacity. It is also a hydrophilic material that has a high density of reactive functional groups [24,25]. The functional groups are essential for the blending of a polymer with CS polymer. This methodology has attracted the attention of many researcher groups in which new materials can be prepared. The blended polymers exhibit superior properties compared to the individual polymers [26,27]. The blended polymers are copolymers that contain two polymers which combined via secondary forces, such as van der Waals and H-bonding [28,29]. An earlier study has shown that improving the conductivity of a particular polymer electrolyte can be achieved via blending with another polymer [27]. In dealing with the conductivity of polymer electrolytes, the ion relaxation and charge transport mechanism have to be evaluated [30]. According to fundamental principles, there has been no complete understanding of the mechanism of ionic conduction within the polymer. This is due to the complexity of the process of ionic conduction within these materials in which several factors contribute-for example, degree of salt dissociation, salt concentration, the dielectric constant of host polymer, the tendency of ion to aggregate, and polymer chains' mobility [31-34]. The analysis of ionic conductivity of polymer electrolytes via dielectric properties provides insight into the eligibility of polymer of interest in large scale. It is also well-known that the study of dielectric relaxation phenomena leads to understanding ion transport mechanisms, including the extent of ionic/molecular interaction in SPE systems [35].

In this work, lithium perchlorate $\left(\mathrm{LiClO}_{4}\right)$ was used as a salt owing to its low lattice energy. $\mathrm{LiClO}_{4}$ consists of a large size anion a small size cation. The ionic conductivity is influenced by the diffusion rate of cations and anions which depends on the ion size. $\mathrm{LiClO}_{4}$ is selected owing to its good conductivity and ease of complex creation in the fabrication of SPEs [36]. Therefore, $\mathrm{LiClO}_{4}$ is more promising in comparison with other lithium salts owing to the low interfacial resistance when 
lithium metal was used as anode. Moreover, $\mathrm{LiClO}_{4}$ possesses large dissociation energy, hence it is a good soluble in most solvents [37]. In this work, glycerol is also used as plasticizer to enhance ionic conductivity. Pawlicka et al. [38] documented an increase from $\sim 10^{-8}$ to $10^{-4} \mathrm{~S} \mathrm{~cm}^{-1}$ with the help of glycerol in their electrolyte systems. High dielectric constant of glycerol weakens the electrostatic force among the cations and anions of the salt which can create more mobile ions. The plasticizer can also enhance the amorphous structure of the electrolyte [39].

Electrochemical double-layer capacitor (EDLC) is a device where the energy storage mechanism occurs owing to accumulation of ions at the interfaces between the blocking electrodes and electrolytes. EDLCs have long lifetimes, high power density, fast charge/discharge and identical carbonaceous electrodes [40-42]. There are many reports that used polymer electrolytes in EDLC fabrication [40-42]. In this study, the highest conducting electrolyte was employed in the fabrication of EDLCs. In the current work, the dielectric properties and relaxation dynamics of polymer electrolytes based on PVA:CS: $\mathrm{LiClO}_{4}$ plasticized with glycerol have been analyzed for the first time. Here, the dielectric and electrical modulus properties of plasticized polymer electrolyte PVA:CS:LiClO 4 and its energy storage capacity (i.e., electric double-layer capacitor) have been studied.

\section{Experimental}

\subsection{Materials and Preparation of Blend SPE Films}

The chitosan (CS) with average molecular weight of 310,000-375,000 $\mathrm{g} \mathrm{mol}^{-1}$, PVA with an average molecular weight of $35000 \mathrm{~g} \mathrm{~mol}^{-1}$, Lithium perchlorate $\left(\mathrm{LiClO}_{4}\right)$ salt, and acetic acid $\left(\mathrm{CH}_{3} \mathrm{COOH}\right)$ solution have been used in the preparation of PVA:CS: $\mathrm{LiClO}_{4}$ blend SPE films. The solution cast technique was used in the film preparation.

All chemicals that were used as obtained were purchased from the (Sigma-Aldrich, Kuala Lumpur, Malaysia). In this work, $0.5 \mathrm{~g}$ of CS was dissolved in $30 \mathrm{~mL}$ of the solution of $1 \%$ acetic acid $\left(\mathrm{CH}_{3} \mathrm{COOH}\right)$ and then stirred at room temperature for $3 \mathrm{~h}$. $0.5 \mathrm{~g}$ of PVA was dissolved in $20 \mathrm{~mL}$ of distilled water at $80{ }^{\circ} \mathrm{C}$ during PVA preparation. The solution was left at room temperature to cool down. Then, both solutions were mixed with continuous stirring using a magnetic stirrer. Afterwards, $40 \mathrm{wt} \%$ of lithium perchlorate $\left(\mathrm{LiClO}_{4}\right)$ salt as a dopant was added into the solution mixture with stirring continuously until a clear solution was gained. To plasticization of the solution mixture, various quantities of glycerol were added ranged from 14 to $42 \mathrm{wt} \%$. Based on the addition amount of $14 \mathrm{wt} \%, 28 \mathrm{wt} \%$, and $42 \mathrm{wt} \%$ of glycerol to the PVA:CS:LiClO 4 system, the prepared polymer blend electrolyte samples were coded as PVCSG1, PVCSG2, PVCSG3, respectively. Mixtures of the final solution were eventually poured into dry and clean glass Petri dishes. They were left to evaporate gradually at room temperature. Thereby, dry and free-standing of PVA:CS:LiClO $4: g l y c e r o l$ blend SPE films were obtained. The highest conducting plasticized electrolyte system (PVCSG3) was used for electric double-layer capacitor (EDLC) device application.

\subsection{Impedance and Equivalent Circuit Modeling Studies (EIS)}

In the analysis of electrochemical properties of materials utilized in solid-state batteries, complex impedance spectroscopy (CIS) can be used as a powerful technique [32-34]. This approach provides insight into the electrical properties of bulk materials as well as the interface region of the electronically conductive electrodes. The small discs as electrode separator of $2 \mathrm{~cm}$ in diameter from SPE films were constructed and then sandwiched between two stainless steel electrodes using spring pressure. Impedance measurements of the films were carried out using the HIOKI $3531 \mathrm{Z}$ Hi-tester (Nagano, Japan) in a frequency range of 50-5000 kHz. The measurements were managed by customized software, in which the impedance spectrum with real and imaginary parts could be given. The impedance spectra were exhibited in the Nyquist plot. The bulk resistance $\left(R_{b}\right)$ values were 
obtained from the intercept of the spike with the real part on the x-axis of the spectra. The conductivity values were calculated from the relationship shown below [32]

$$
\sigma_{d c}=\left(\frac{1}{R_{b}}\right) \times\left(\frac{t}{A}\right)
$$

where; $t$ and $A$ are the thickness and area of the film, respectively.

The real $\left(Z_{r}\right)$ and imaginary $\left(Z_{i}\right)$ parts of the complex impedance $\left(Z^{*}\right)$ were used for the evaluation of dielectric constant using the equations [29]

$$
\begin{aligned}
\varepsilon^{\prime} & =\frac{Z_{i}}{\omega C_{o}\left(Z_{r}^{2}+Z_{i}^{2}\right)} \\
\varepsilon^{\prime \prime} & =\frac{Z^{\prime}}{\omega C_{o}\left(Z^{\prime 2}+Z^{\prime \prime 2}\right)}
\end{aligned}
$$

where $C_{0}$ is the vacuum capacitance determined from $\varepsilon_{0} A / t$. The $\varepsilon_{0}$ is the permittivity of free space $\left(8.85 \times 10^{-12} \mathrm{~F} / \mathrm{m}\right)$. The angular frequency $\omega$ is equivalent to $\omega=2 \pi f$, where; $f$ is the applied field frequency. The $Z_{\mathrm{r}}$ and $Z_{\mathrm{i}}$ data were collected from the EIS data and then used to determine the $\varepsilon^{\prime}$ and $\varepsilon^{\prime \prime}$ data.

\subsection{TNM and LSV Analyses}

To obtain the ionic and electronic transference numbers ( $t_{\text {ion }}$ and $t_{e}$ ), the V \& A instrument DP3003 digital control DC power supply was used by DC polarization method. The highest conducting plasticized sample (i.e., PVCSG3) was placed between a pair of stainless steel (SS) blocking electrodes. A $0.2 \mathrm{~V}$ constant working voltage was applied to polarize the cell at room temperature. To see the highest working voltage of the PVCSG3 system, the linear sweep voltammetry (LSV) was done using a Digi-IVY DY2300 potentiostat. In the voltage range of 0 to $2.5 \mathrm{~V}$, the LSV was measured at a scan rate of $10 \mathrm{mV} / \mathrm{s}$.

\subsection{Construction and Characterization of EDLC}

To construct the EDLC for testing, the carbon electrodes were prepared first. For the blending of $6.25 \%$ carbon black powder and $81.25 \%$ activated carbon, a planetary ball miller was used. Meanwhile, in $15 \mathrm{~mL}$ of N-methyl pyrrolidone (NMP), $12.5 \mathrm{wt} \%$ of polyvinylidene fluoride (PVdF) was dissolved. Subsequently, the mixture of the powders was poured into the PVdF-NMP solution followed by stirring before a thick black solution emerged. Then, the black solution was coated with a doctor's blade on an aluminum foil (AF). The drying process for the coated AF was carried out at a temperature of $60{ }^{\circ} \mathrm{C}$ in an oven. Ultimately, the electrodes were stored in a desiccator to make sure of dryness before measurements. In order to calculate the decisive parameters of the EDLC, such as equivalent series resistance $\left(R_{e s}\right)$, specific capacitance from charge-discharge $\left(C_{C D}\right)$, energy $(E)$, and power density $(P)$, the current density was kept at $0.5 \mathrm{~mA} / \mathrm{cm}^{2}$.

\section{Results and Discussion}

\subsection{Impedance and Electrical Equivalent Circuit Studies}

It is well known that two factors, the number of ion carriers and their mobility determine the materials and polymers' ionic conductivity. To deal with these factors in polymer-based electrolytes, impedance spectroscopy is a candidate that characterized by simplicity and powerfulness $[43,44]$. During data analysis, a suitable electrical equivalent circuit (EEC) model was suggested. The EEC as quick and straightforward is often used in the analysis of impedance data points that provides a comprehensive picture of the whole system $[45,46]$. The resistance and circuit components of the EEC modeling are associated with the samples' electrical properties. The fitting process of the impedance 
spectra with the EEC model for all the plasticized samples is presented in Figure 1a-c. It is seen that the impedance of the films is a spike-like shape.
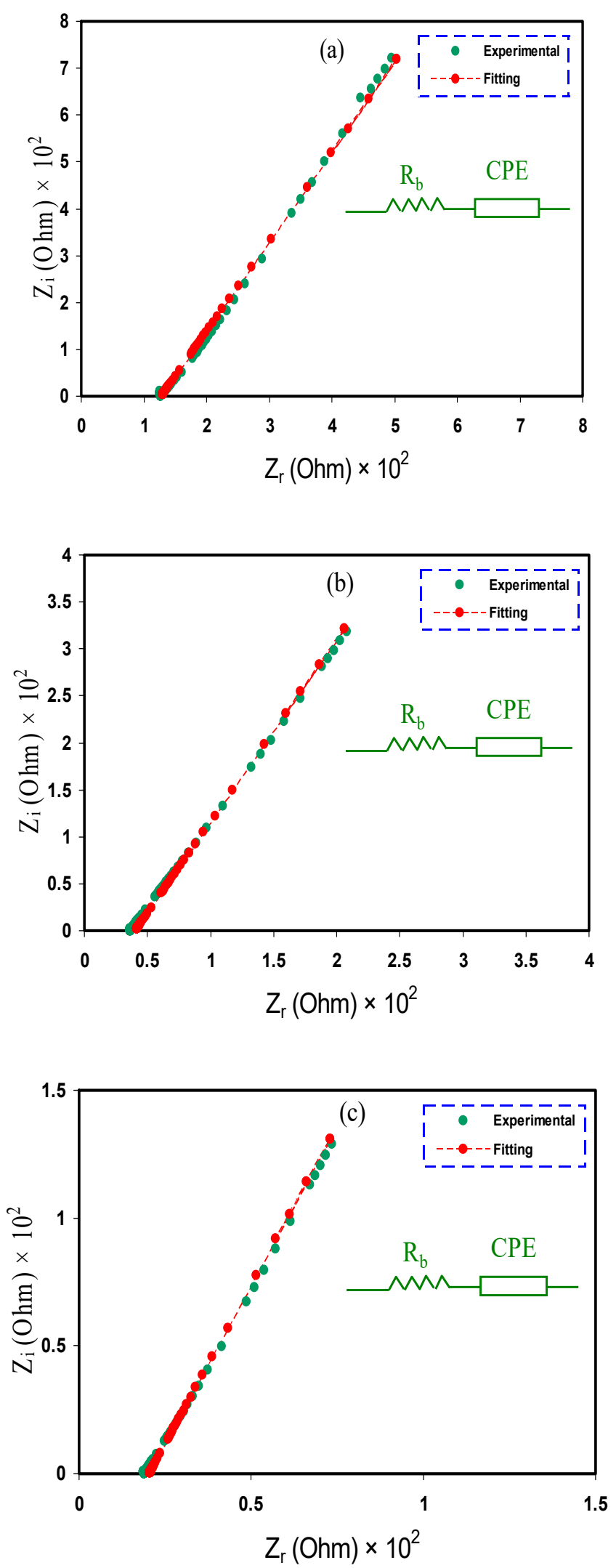

Figure 1. EIS plots for (a) PVCSG1, (b) PVCSG2, and (c) PVCSG3 electrolyte films. 
The EDLC at the electrode/electrolyte interface in an electrochemical cell is created by the motion of cations and anions toward the electrodes in opposite directions. The blocking of the electrode surface was taken into consideration in the impedance analysis. In the impedance spectra, the indication of capacitor system should appear in the form of a vertical spike (by presuming it is ideal) [32,47]. The creation of double-layer capacitance between the electrodes and the electrolyte blend in the form of constant phase element (CPE) can be recognized from the low-frequency region response. In the equivalent circuit of electrochemical processes, CPE is usually used other than the ideal capacitor in the real system [48]. The plasticized electrolytes' spike feature indicates that the polymer modeling's resistive component is predominated $[9,49]$.

The $Z_{C P E}$ impedance can be written as $[31,48]$ :

$$
Z_{C P E}=\frac{1}{C \omega^{n}}\left[\cos \left(\frac{\pi n}{2}\right)-i \sin \left(\frac{\pi n}{2}\right)\right]
$$

In this case, the values of $Z_{r}$ and $Z_{i}$ are correlated with the EEC, which can be expressed, mathematically, as

$$
\begin{gathered}
Z_{r}=R+\frac{\cos (\pi n / 2)}{C \omega^{n}} \\
Z_{i}=\frac{\sin (\pi n / 2)}{C \omega^{n}}
\end{gathered}
$$

where $C$ is the CPE capacitance, $\omega$ is the angular frequency, and $n$ is related to the deviation in the complex impedance spectra at the vertical axis. The EEC fitting parameters are shown in Table 1.

Table 1. EEC fitting parameters for PVA:CS: $\mathrm{LiClO}_{4}$ : glycerol systems at room temperature.

\begin{tabular}{cccc}
\hline Sample & P(rad) & K (F $\left.^{-\mathbf{1}}\right)$ & $\mathbf{C}(\mathbf{F})$ \\
\hline PVCSG1 & 0.693 & $4.39 \times 10^{4}$ & $2.28 \times 10^{-5}$ \\
PVCSG2 & 0.697 & $1.99 \times 10^{4}$ & $5.03 \times 10^{-5}$ \\
PVCSG3 & 0.3716 & $1.10 \times 10^{4}$ & $9.09 \times 10^{-5}$ \\
\hline
\end{tabular}

Table 2 presents the DC conductivity values at room temperature for the plasticized polymer blend electrolytes. It is seen that the value of DC conductivity increases with increasing the quantity of glycerol quantity. The relatively high DC conductivity value of about $8.457 \times 10^{-4} \mathrm{~S} / \mathrm{cm}$ is seen for the sample incorporated with $42 \mathrm{wt} \%$ glycerol. Solvent-free polymer electrolytes with DC ionic conductivities $\left(\sigma_{\mathrm{dc}}\right)$ have been previously documented in the $10^{-5}-10^{-2} \mathrm{~S} / \mathrm{cm}$ range at room and different temperatures [50-53]. Cevik and Bozkurt [42] synthesized polymer metal electrolyte poly(acrylic acid) (PAA)-cobalt sulfate (Co) with the DC ionic conductivity of $3.15 \times 10^{-4} \mathrm{~S} / \mathrm{cm}$. The authors used the electrolyte for application in EDLC with high performance. It is possible to rationalize the contribution of both the segmental motion and ionic conductivity to the whole conductivity in various ways. Herein, a mathematical relationship between DC conductivity $\left(\sigma_{d c}\right)$ on one side and charge $\left(q_{i}\right)$, charge carrier concentration $\left(n_{i}\right)$, and the charge carrier mobility $\left(\mu_{i}\right)$ on other can be expressed from the well-known equation [50],

$$
\sigma=\Sigma n_{i} q_{i} \mu_{i}
$$

Table 2. DC conductivity values for PVA:CS: $\mathrm{LiClO}_{4}$ : glycerol systems.

\begin{tabular}{cc}
\hline Sample Designation & DC Conductivity $(\mathrm{S} / \mathrm{cm})$ \\
\hline PVCSG1 & $1.409 \times 10^{-4}$ \\
PVCSG2 & $4.228 \times 10^{-4}$ \\
PVCSG3 & $8.457 \times 10^{-4}$ \\
\hline
\end{tabular}


From the above equation, it is obvious that the increase in DC conductivity is mainly governed by the number of ions rather than ion mobility at room temperature. On the one hand, the number of ions is controlled by the salt concentration; on the other hand, mobility has been increased through glycerol as a plasticizer.

As the impedance data consists of a spike only, the ionic transport parameters of mobility $(\mu)$, diffusion coefficient $(D)$, and number density $(n)$ of ions were obtained using the following equations, which are obtained in detail in [48,54-56].

The $D$ of the ion carriers of the systems can be obtained by the equation below,

$$
D=D_{o} \exp \left\{-0.0297\left[\ln D_{o}\right]^{2}-1.4348 \ln D_{o}-14.504\right\}
$$

where

$$
D_{o}=\left(\frac{4 k^{2} l^{2}}{R_{b}^{4} \omega 3_{\text {min }}}\right)
$$

where $l$ is the electrolyte thickness and $\omega_{\min }$ is the angular frequency, which corresponds to the minimum $Z_{i}$.

The mobility $(\mu)$ of the ion carriers can be obtained from the following equation,

$$
\mu=\left(\frac{e D}{K_{b} T}\right)
$$

where $T$ is the absolute temperature and $k_{b}$ is the Boltzmann constant.

For better understanding, the diffusion coefficient and mobility for each cation and anion were

\begin{tabular}{|c|c|c|c|c|c|c|c|c|}
\hline Sample & $\begin{array}{c}\omega \\
\left(\operatorname{rad~s}^{-1}\right)\end{array}$ & $\begin{array}{c}D \\
\left(\mathrm{~cm}^{2} \mathrm{~s}^{-1}\right)\end{array}$ & $\begin{array}{c}\mu \\
\left(\mathrm{cm}^{2} \mathrm{~V}^{-1} \mathrm{~s}\right)\end{array}$ & $\begin{array}{c}n \\
\left(\mathrm{~cm}^{-3}\right)\end{array}$ & $\begin{array}{c}D_{+} \\
\left(\mathrm{cm}^{2} \mathrm{~s}^{-1}\right)\end{array}$ & $\begin{array}{c}D_{-} \\
\left(\mathrm{cm}^{2} \mathrm{~s}^{-1}\right)\end{array}$ & $\begin{array}{c}\mu_{+} \\
\left(\mathrm{cm}^{2} \mathrm{~V}^{-1} \mathrm{~s}\right)\end{array}$ & $\begin{array}{c}\mu_{-} \\
\left(\mathrm{cm}^{2} \mathrm{~V}^{-1} \mathrm{~s}\right)\end{array}$ \\
\hline PVCSG1 & $4.78 \times 10^{5}$ & $4.59 \times 10^{-9}$ & $1.79 \times 10^{-7}$ & $4.92 \times 10^{21}$ & $4.54 \times 10^{-9}$ & $5.04 \times 10^{-11}$ & $1.77 \times 10^{-7}$ & $1.96 \times 10^{-9}$ \\
\hline PVCSG2 & $5.65 \times 10^{5}$ & $1.28 \times 10^{-8}$ & $5.01 \times 10^{-7}$ & $5.27 \times 10^{21}$ & $1.27 \times 10^{-8}$ & $1.41 \times 10^{-10}$ & $4.95 \times 10^{-7}$ & $5.51 \times 10^{-9}$ \\
\hline PVCSG3 & $5.59 \times 10^{5}$ & $2.12 \times 10^{-8}$ & $8.25 \times 10^{-7}$ & $6.4 \times 10^{21}$ & $2.09 \times 10^{-8}$ & $2.33 \times 10^{-10}$ & $8.16 \times 10^{-7}$ & $9.07 \times 10^{-9}$ \\
\hline
\end{tabular}
determined and listed them in Table 3 and also explained in detail in the next sections.

Table 3. Values of $\omega$ and ion transport parameters at room temperature.

Since DC conductivity of ions is shown by

$$
\sigma_{D c}=n e \mu
$$

Thus, the number density of ion carriers $(n)$ is obtained by Equation (11).

Table 3 indicates the ion transport parameters and the $\omega_{\min }$ values for the systems. Based on Table 3, it is observed that the D value increases as the amount of glycerol increase from 14 to $42 \mathrm{wt} \%$. The same trend is seen in $\mu$, as shown in Table 3, where $\mu$ increases. The increase of $\mu$ and $D$ is attributed to the improvement in chain flexibility with the presence of glycerol. When the amount of glycerol is increased, the values of $D, \mu$, and $n$ are increased, contributing to increasing conductivity. This is because the further glycerol insertion dissociates additional salts to free ions, thereby increasing the density of the ion carriers [48].

\subsection{Dielectric Properties}

The complex permittivity function $\left(\varepsilon^{*}(\omega)=\varepsilon^{\prime}(\omega)+\varepsilon^{\prime \prime}(\omega)\right)$ is the property of materials that depends on the frequency of the applied field, temperature, and structure and composition of polymer electrolytes [57-59]. It has been confirmed that the study of dielectric constant is the crucial parameter for determining the conductivity behavior of polymer electrolytes and understanding the mechanism 
of ion transport [34,60-62]. The dielectric constant $\left(\varepsilon^{\prime}\right)$ and dielectric loss $\left(\varepsilon^{\prime \prime}\right)$ were determined using Equations (2) and (3).

Figure $2 \mathrm{a}, \mathrm{b}$ exhibit the continuous variation of dielectric constant $\left(\varepsilon^{\prime}\right)$ and dielectric loss $\left(\varepsilon^{\prime \prime}\right)$ over the frequency range of each plasticized film. It is seen that the value of $\varepsilon^{\prime}$ reaches its maximum value in the low-frequency region. Such maximum value of $\varepsilon^{\prime}$ at the low-frequency can be correlated to the charge accumulation at the interfacial region $[32,33,62]$. It is also observed that the value of $\varepsilon^{\prime}$ begin to drop in the high-frequency region. This dropping in $\varepsilon^{\prime}$ value is attributed to the limitation of ion diffusion. It is also significant that the dipole molecules do not have enough time to change their orientation in the applied electrical field [60-62]. It is seen that the $\varepsilon^{\prime}$ reaches the maximum value at $42 \mathrm{wt} \%$ of glycerol, and then reduces the value for other amounts of glycerol. Profoundly, the high $\varepsilon^{\prime}$ is a decisive factor where the salt's dissociation means more ions participating in polarization and the conduction process $[34,62]$.
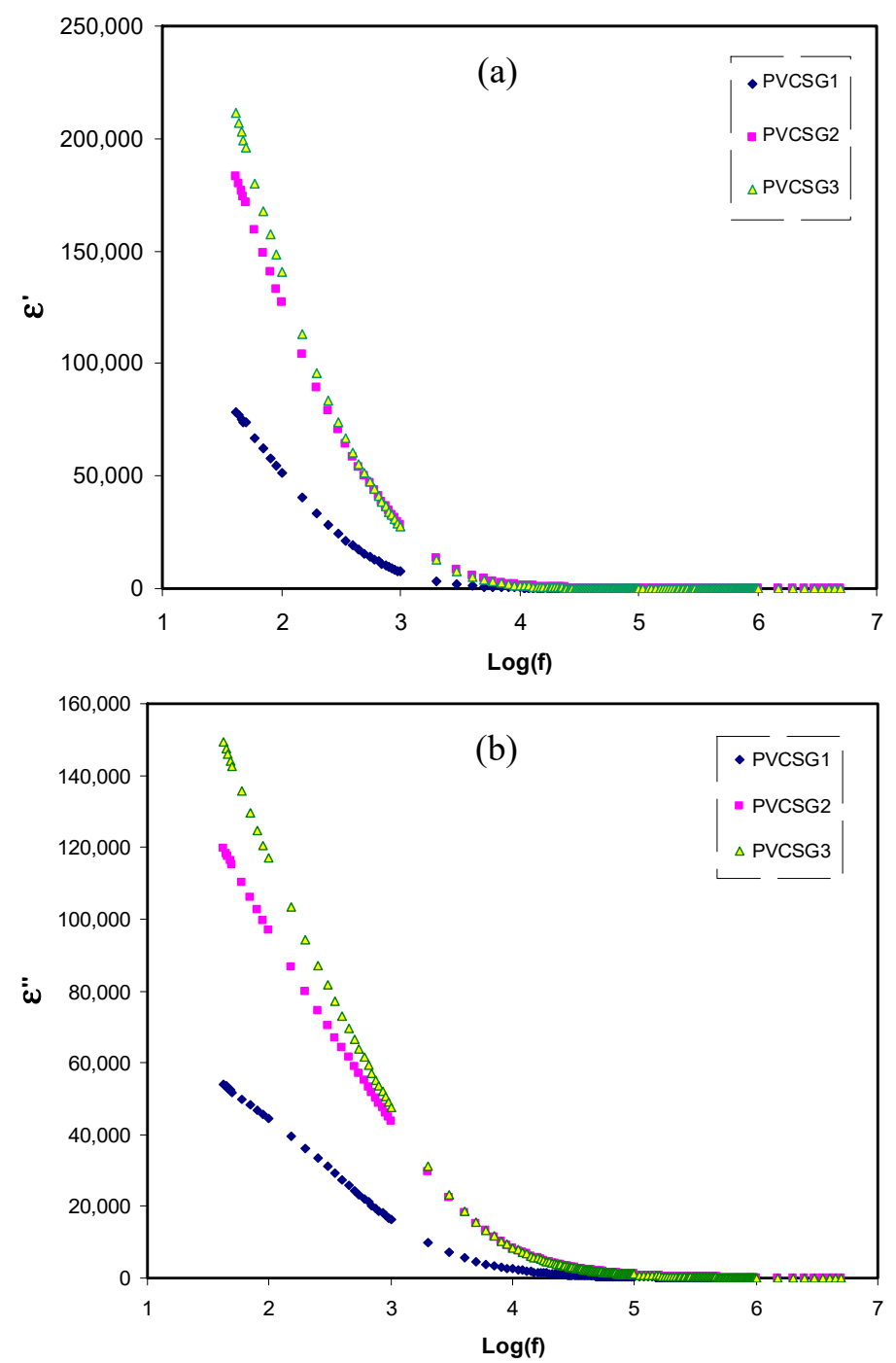

Figure 2. Dielectric parameters of (a) dielectric constant and (b) dielectric loss vs. $\log (\mathrm{f})$ for all plasticized electrolyte samples.

There is a function between DC conductivity and $\varepsilon^{\prime}$ in one side and ion movement and polarization on the other side. It is seen that the trends of $\varepsilon^{\prime}$ and DC conductivity are similar, indicating that $\varepsilon^{\prime}$ investigation is a proper property from which one can tackle the conductivity behavior of polymer 
electrolytes. It is well-established, mathematically, that the carrier density is directly connected to the dielectric constant $\left(\varepsilon^{\prime}\right)$ and dissociation energy $(U)$, which can be understood through the relationship

$$
n=n_{o} \exp \left(-\frac{U}{\varepsilon^{\prime} K T}\right)
$$

The increase in the $\varepsilon^{\prime}$ value with glycerol addition results in an increase in charge carrier concentration and DC conductivity $[4,32,34]$.

\subsection{TNM and LSV Studies}

Utilization of benign electrolytes, particularly solid polymer electrolytes (SPEs) is of great importance in electrochemical device application $[63,64]$. Although SPEs were introduced and studied since the late 1970s, they have still been considered as one of the leading topics [1,47]. It is necessary to perform the transference number analysis (TNM) and linear sweep voltammetry (LSV) to test polymer electrolytes for use in large scale applications. From the TNM analysis, one can determine the dominant charge carrier within polymer electrolytes. The ion transference number $\left(t_{\text {ion }}\right)$ of polymer electrolyte samples can be examined via DC polarization technique. In this technique, DC voltages are scanned in an electrochemical cell sample within the potential window, followed by recording corresponding current values in an experimental time scale (see Figure 3) [65]. In the electrochemical cell, the relatively high conductive polymer electrolyte was placed between a pair of stainless steel blocking electrodes (SS) to perform electrochemical measurements including both the ion ( $\left.t_{\text {ion }}\right)$ and the electron $\left(\mathrm{t}_{\mathrm{e}}\right)$ transference numbers using the relationship $[31,48,55]$

$$
\begin{gathered}
t_{i o n}=\frac{I_{i}-I_{S S}}{I_{i}} \\
t_{e}=1-t_{\text {ion }}
\end{gathered}
$$

where $I_{S S}$ and $I_{i}$ are the steady-state current and initial current, respectively. The immense value of the initial current can be attributed to the contribution of both ion and electron $[53,66,67]$. It is known that the used electrodes are stainless steels which prevent ion-transport (ion blocking phenomenon); thereby, a substantial drop of current is noticed before steady-state constant current value at $0.1 \mu \mathrm{A}$. This phenomenon indicates the behavior of an ionic nature of the polymer electrolyte system [68]. Moreover, the values of $t_{i o n}=0.989$ and $t_{e l}=0.011$ confirm dominancy of ion to carry charge within the polymer electrolyte. Furthermore, the proximity of $t_{i o n}$ to 1 as ideal value is actually crucial for dealing with the mechanism of conduction in such particular polymer electrolyte system $[65,69,70]$.

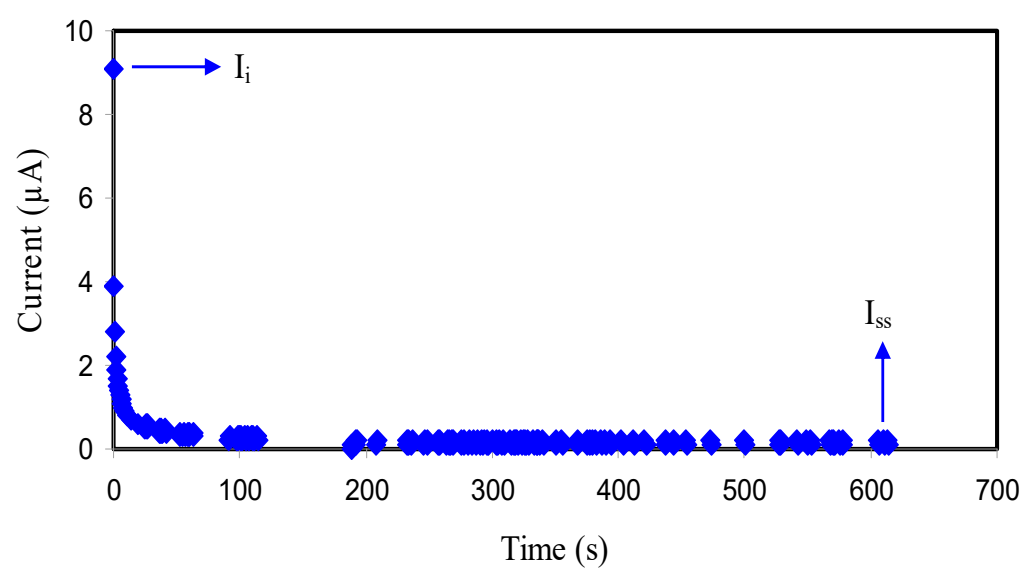

Figure 3. Variation of current with respect to time for the cell assembled with SS/CS:PVA:LiClO 
The voltage window of the polymer electrolyte system is of vital importance in terms of large-scale utilization [71,72]. The LSV was applied as an efficient technique to determine the voltage window polymer electrolyte. Figure 4 presents a typical LSV response of relatively high conducting CS:PVA: $\mathrm{LiClO}_{4}$ blend electrolyte. It is seen that the voltage window range of the polymer blend electrolyte is $1.94 \mathrm{~V}$ that is satisfactory to be utilized in EDLC [73]. Monisha et al. [74] have noted that the threshold voltage is the flow of current through the cells. Bockenfeld et al. [75] used protic ionic liquids as electrolyte for lithium-ion batteries. The authors indicated that the electrolyte $0.5 \mathrm{M}$ lithium nitrate $\left(\mathrm{LiNO}_{3}\right)$ in propylene carbonate $(\mathrm{PC})$-pyrrolidinium nitrate $\left(\mathrm{PYRNO}_{3}\right)$ displayed the overall electrochemical stability window of $2.65 \mathrm{~V}$. They illustrated that the electrochemical stability value is large enough to guarantee a safe extraction and insertion of lithium into lithium iron phosphate $\left(\mathrm{LiFePO}_{4}, \mathrm{LFP}\right)$ electrode.

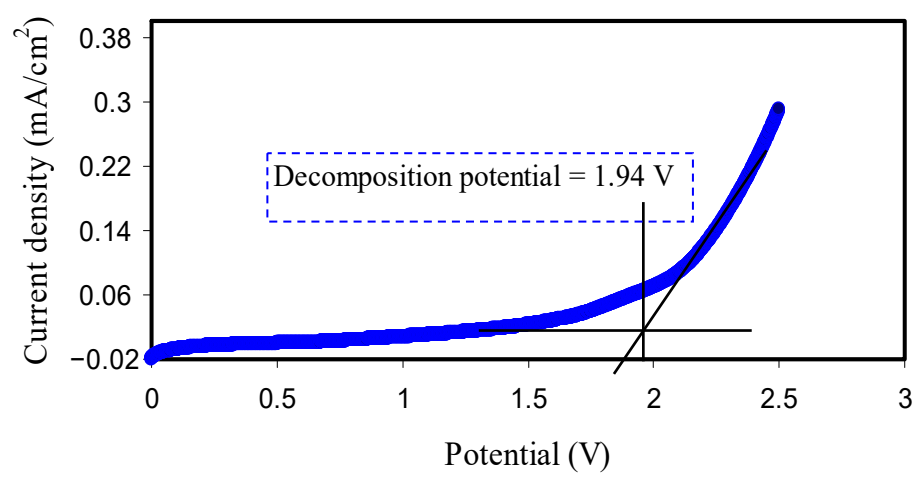

Figure 4. LSV curve for the cell with SS/CS:PVA:LiClO 4 :glycerol/SS at scan rate of $10 \mathrm{mV} / \mathrm{s}$ at ambient temperature.

From the DC conductivity and transference number of ions $\left(t_{i o n}\right)$ values, the diffusion coefficient and mobility of cations and anions of all polymer electrolytes were calculated by the following equations [76].

$$
\begin{gathered}
D=k T \sigma / n e^{2} \\
D=D_{+}+D_{-} \\
t_{\text {ion }}=D_{+} /\left(D_{+}+D_{-}\right) \\
\mu=\sigma / n e \\
\mu=\mu_{+}+\mu_{-} \\
t_{\text {ion }}=\mu_{+} /\left(\mu_{+}+\mu_{-}\right)
\end{gathered}
$$

where $k$ is Boltzmann constant, $T$ is the absolute temperature, $\sigma$ is the conductivity, and $e$ is the charge of electrons, $D_{+}$is the diffusion coefficient of cation, $D_{-}$is the diffusion coefficient of anion, $\mu_{+}$is the mobility of cation and $\mu_{-}$is the mobility of anion. The size of cations are smaller than the anions and this is a reason why $\mu_{+}$is larger than the $\mu_{-}$. Table 3 shows that the $D_{+}$and $\mu_{+}$are greater than the $D_{-}$and $\mu_{-}$, respectively. When the conductivity increases, the $\mu_{+}$and $\mu_{-}$also increase and vice versa. The similar behavior is reflected for $D_{+}$and $D_{-}$. Therefore, the transference number measurement (TNM) leads to the conclusion that the DC conductivity was influenced by $D_{+}$and $\mu_{+}$. The highest conducting plasticized electrolyte has the maximum value of ionic mobility and diffusion coefficient in comparison with the other plasticized electrolytes.

\subsection{Cyclic Voltammetry Test for the EDLC Device}

Cyclic voltammetry (CV) as an informative technique can be used to evaluate EDLCs in terms of qualitative and quantitative aspects [26,77]. Minakshi et al. [78] illustrated that the electrochemical 
energy storage of sodium and lithium ions from aqueous solution in binary metal oxides is vital for applications in renewable energy storage. They described the binary metal oxides as novel electrode materials for supercapacitors. The authors used CV to evaluate the electrochemical behavior of the symmetric capacitor. Biswal et al. [79] synthesized hierarchical porous cobalt-nickel-iron (Co-Ni-Fe) ternary oxide heterostructure as an electrode for hybrid capacitor application owing to their high redox potentials. They investigated the electrochemical behavior of the $\mathrm{Co}-\mathrm{Ni}-\mathrm{Fe}$ ternary hydroxides using CV at different scan rates. The CV curve showed an elliptical at high scan rates, deviated from rectangular shape, representing a large resistance of the fabricated material has a dominant role and a slight contribution from electron transfer reaction of electrolyte ions at the ternary oxides interface.

In our study, the CV was carried out at sweep rate of $5,10,20$, and $50 \mathrm{mV} / \mathrm{s}$ as shown in Figure 5. It is seen from the $\mathrm{CV}$ response that there is no redox peak (Faradaic process) in the voltage range of 0 to $0.9 \mathrm{~V}$. Instead, the non-Faradaic response occurs as a result of electrical double layer formation $[16,80]$. This phenomenon is desired in EDLCs and supercapacitors [81]. This also rationalizes the charging storage process mechanism in EDLC as a consequence of ion accumulation at the electrode-electrolyte interface in response to an electric potential application [51,82]. There is a deviation of the rectangular shape of the CV response at higher scan rates, as shown in Figure 5. According to Panday and coworkers, the deviation from the perfect rectangular shape results from the gradual build-up of the electric double layer [83]. The CV curve deviates from rectangular to elliptical shape, which is due to carbon porosity and internal resistance, thus resulting to a current-voltage dependence [48]. Brza et al. [48] showed that the ions migrate very fast toward the surface of the electrodes at higher scan rates and thus the ions cannot form a proper double layer. This is why the current is not stable and it depends on the voltage. The specific capacitance $\left(C_{\text {spe }}\right)$ of the EDLC assembly can be obtained from the CV response via the equation $[16,31]$

$$
C_{\text {spe }}=\int_{V_{i}}^{V_{f}} \frac{I(V) d V}{2 m v\left(V_{f}-V_{i}\right)}
$$

where $I(V) d V$ refers to the area of the CV response, which is calculated by Origin 9.0 software via the integration function. In this work, $V_{i}$ and $V_{f}$ are set to 0 and $0.9 \mathrm{~V}$, respectively. The $m$ and $v$ parameters refer to the mass of active material used and sweep rate, respectively. Table 4 presents the values of $C_{\text {spe }}$ obtained from the CV. The values can be compared to those derived from the charge-discharge graph of the EDLC in the next section.

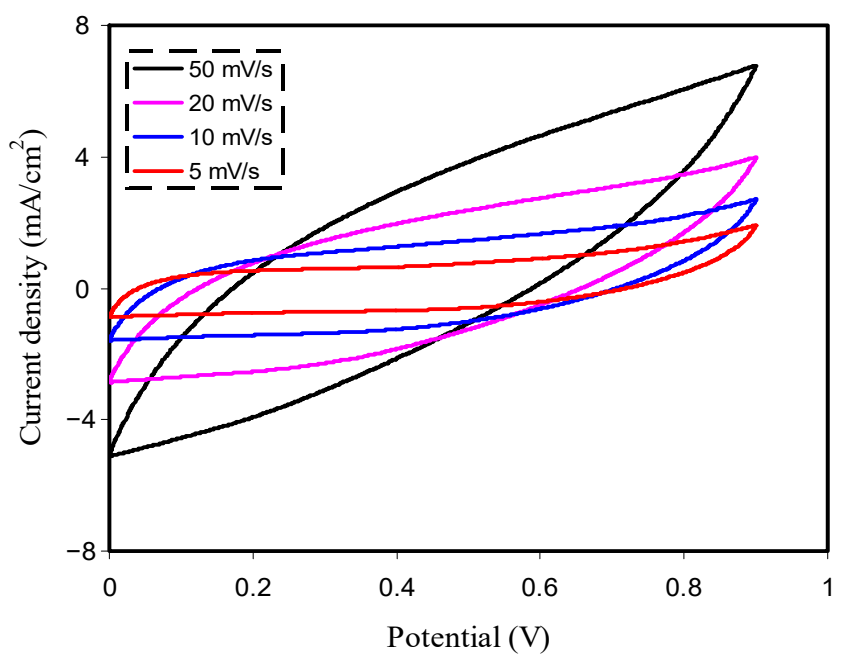

Figure 5. Cyclic voltammetry (CV) plot of the fabricated EDLC for PVCSG3 film in the potential range of $0-0.9 \mathrm{~V}$. 


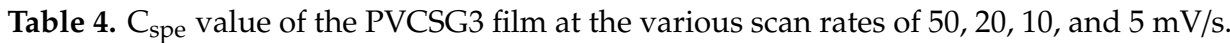

\begin{tabular}{cc}
\hline Scan Rate (mV/s) & Capacitance (F/g) \\
\hline 50 & 31.09 \\
20 & 57.61 \\
10 & 80.70 \\
5 & 94.65 \\
\hline
\end{tabular}

\subsection{Galvanostatic Charge-Discharge (CDG) Study}

The charge-discharge profiles of the fabricated EDLC were obtained by holding the current density at $0.5 \mathrm{~mA} \mathrm{~cm}^{-2}$ in the potential range of 0 to $0.9 \mathrm{~V}$, as shown in Figure 6. The discharge/charge current used to obtain the CD curves is $1 \mathrm{~mA}$. The slope of the discharge response is nearly linear, confirming the capacitive behavior of the EDLC $[84,85]$. The specific capacitance $\left(C_{s}\right)$ can be determined from this slope using the equation [31]

$$
C_{S}=\frac{i}{s m}
$$

where $i$ is the constant current, $\mathrm{s}$ is the slope of the GCD discharge line and $m$ is the mass of active material (active carbon). The $C_{s}$ values of the EDLC within 100 cycles have been determined and shown in Figure $7 \mathrm{a}$. At the first cycle, the $C_{s}$ value is $130 \mathrm{~F} \mathrm{~g}^{-1}$. It drops to $70 \mathrm{~F} \mathrm{~g}^{-1}$ at the 50th cycle and becomes constant with a value within 55 to $60 \mathrm{~F} \mathrm{~g}^{-1}$. This value is comparable to the $C_{\text {spe }}$ value obtained from the CV analysis at the scanning rate of $20 \mathrm{mV} \mathrm{s}^{-1}$ (Table 4).

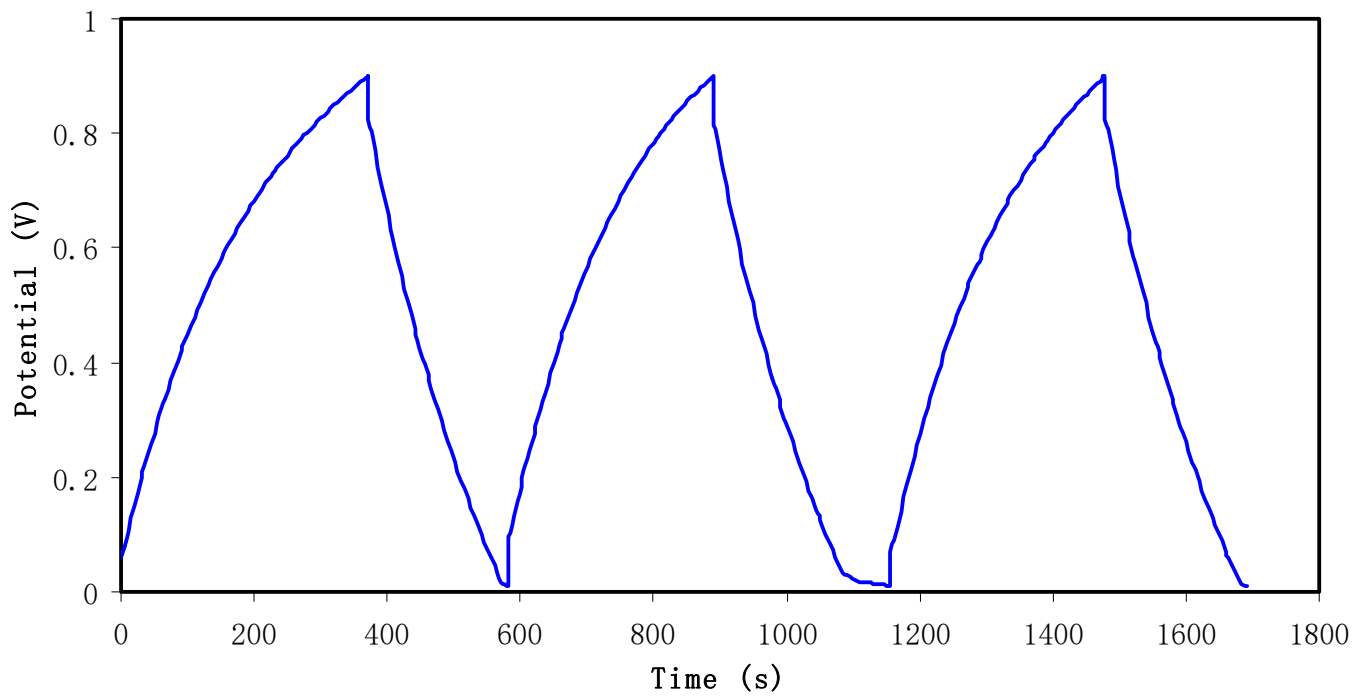

Figure 6. Charge-discharge profiles of the fabricated EDLC at selected cycles.

The trend of decreasing of the $\mathrm{C}_{\mathrm{s}}$ values at higher cycles indicates the depletion of the electrolyte where ion pairs are probably created and contribute to the electrochemical device's instability. The ion pairs and ion aggregation formation cause the decrement in mobile charge carriers' availability in the migration between the electrodes. Therefore, this will decrease the ion adsorption onto the electrodes [86].

A recent publication has shown that for unplasticized CS:PEO: $\mathrm{LiClO}_{4}$ polymer blend electrolyte has a specific capacitance of about $5 \mathrm{Fg}^{-1}$ [87]. Teoh et al. [88] used free $\mathrm{LiClO}_{4}$ plasticizer based on corn starch polymer electrolyte in an EDLC assembly, and the value of $C_{s}$ was $7.1 \mathrm{~F} \mathrm{~g}^{-1}$. In another study, an EDLC assembly possesses specific capacitance values (2.6-3.0 and 1.7-2.1 $\mathrm{F} \mathrm{g}^{-1}$ ) correspond to the Mg-based PEO and Li-based PEO polymer electrolytes incorporated with ionic liquids, respectively [77]. Importantly, the present capacitor has shown a capacitance greater than that reported $\left(61.7 \mathrm{~F} \mathrm{~g}^{-1}\right)$ for ionic liquid-based gel polymer electrolyte system carried out by Mukta Tripathi \& S.K. Tripathi [65]. Moreover, the present specific capacitance value is comparable to that of the gel-based polymer 
electrolytes, $87.3 \mathrm{~F} \mathrm{~g}^{-1}$ and $90 \mathrm{~F} \mathrm{~g}^{-1}$ reported by Boonen et al. [89] and Łatoszyńska et al., respectively [90]. Bockenfeld et al. [75] used protic ionic liquids as electrolyte and lithium iron phosphate $\left(\mathrm{LiFePO}_{4}, \mathrm{LFP}\right)$ as electrode for lithium-ion batteries. The author indicated that the electrolyte $0.5 \mathrm{M}$ lithium nitrate $\left(\mathrm{LiNO}_{3}\right)$ in propylene carbonate (PC)-pyrrolidinium nitrate $\left(\mathrm{PYRNO}_{3}\right)$ guarantees a good cycling stability. The LFP electrode was able to provide a capacity of $134 \mathrm{mAhg}^{-1}$. Based on their results, they illustrated that the protonic ionic liquids as electrolytes for lithium-ion battery is possible.
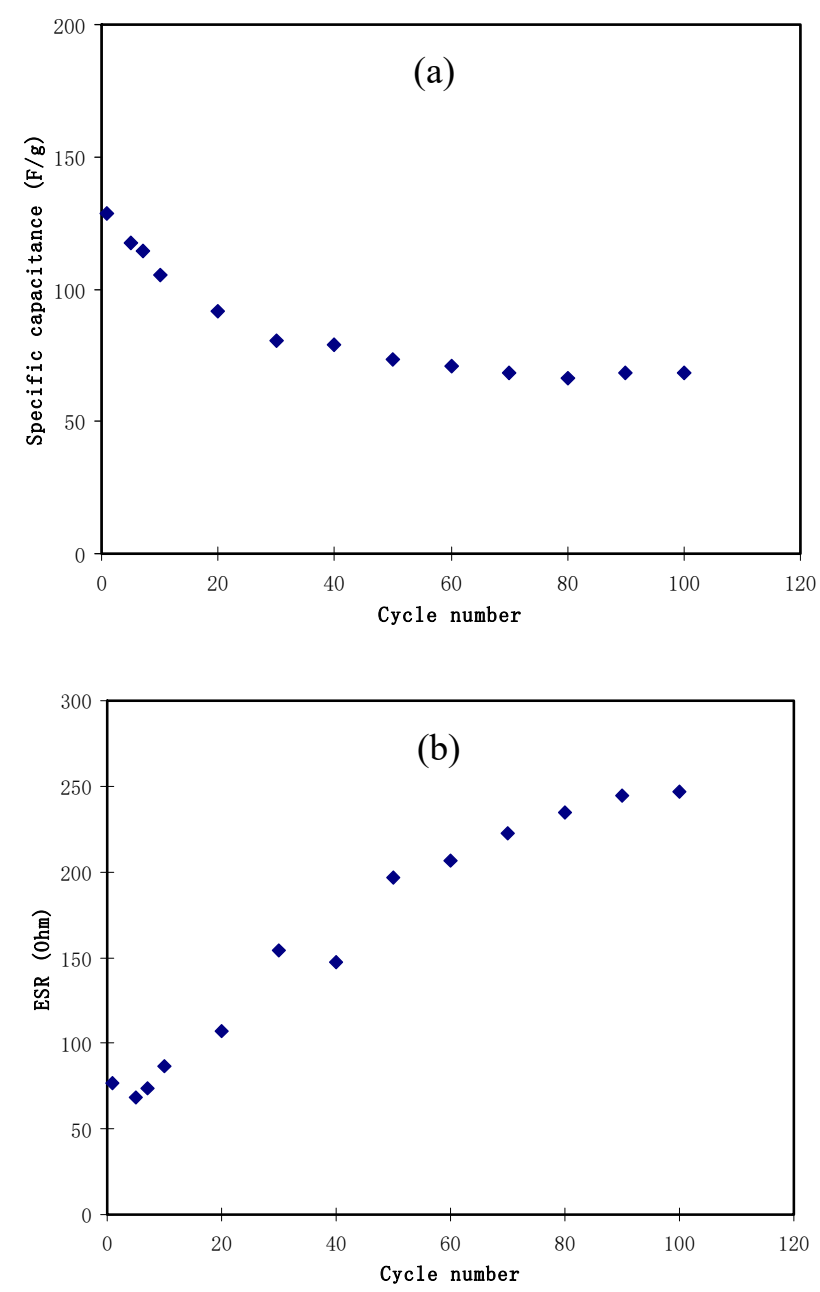

Figure 7. EDLC parameters of (a) specific capacitance and (b) ESR at $0.5 \mathrm{~mA} / \mathrm{cm}^{2}$ for 100 complete cycles.

The redox peaks show intercalation/ deintercalation or Faradaic process, which is different from the energy storage mechanism in EDLC. $\mathrm{Li}^{+}$cation and $\mathrm{ClO}_{4}{ }^{-}$anion migrate toward the electrodes in opposite directions to create the double layer capacitor. The EDLC accumulates energy within adsorption/desorption process or non-Faradaic processes [91-93]. Activated carbon as electrodes of EDLC have large surface area of $2500 \mathrm{~m}^{2} / \mathrm{g}$. Large surface area of activated carbon permits more ions to be adsorbed and thus the double layer is created owing to the ions accumulation [48]. Minakshi et al. [94] investigated amorphous iron phosphate $\left(\mathrm{FePO}_{4}\right)$ as a cathode material electrode for applications in battery using aqueous (potassium hydroxide or lithium hydroxide) electrolytes. The authors investigated lithium intercalation into an $\mathrm{FePO}_{4}$ cathode in an aqueous electrolyte and they identified the lithium intercalation mechanism for $\mathrm{LiOH}$. Minakshi et al. [95] in another study described $\mathrm{Sn}-\mathrm{LiCoPO}_{4}$ battery using aqueous lithium hydroxide electrolyte. They mainly investigated the $\mathrm{LiCoPO}_{4}$ cathode with $\mathrm{Sn}$ as an anode in aqueous $\mathrm{LiOH}$ electrolyte. The authors investigated $\mathrm{Sn}$ as the anode for aqueous secondary batteries so as to enhance the reversible capacity and cyclic efficiency in comparison with the Zn-based anode. 
Another decisive parameter in EDLC is equivalent series resistance $\left(R_{e s r}\right)$, which mathematically can be expressed in the relationship [48].

$$
R_{s}=\frac{V_{d}}{i}
$$

Figure $7 \mathrm{~b}$ presents the $R_{e s r}$ of the EDLC within 100 cycles in which ranged from 80 to $250 \Omega$. There are three causes of internal resistance, which are resistance in the electrolyte, current collectors and current collector-electrolyte gap [70,96]. Importantly, low $R_{e s r}$ value indicates sufficient contact between electrode and electrolyte, confirming ion migration facilitating bulk electrolyte to the electrode surface, resulting in an electrical double-layer formation [97]. The $R_{e s r}$ of the EDLC in this study is relatively low compared to ionic liquid-based-PEO-based polymer electrolyte (i.e., $1300 \Omega$ ) [77].

Finally, other crucial parameters for the EDLC are energy $\left(E_{d e n}\right)$ and power $\left(P_{d e n}\right)$ densities. Energy density measures the quantity of energy that an EDLC can store. Power density is a measure of power that an EDLC can deliver $[48,98]$. Both parameters of $E_{d e n}$ and $P_{d e n}$ can be calculated from the relationships [31,48]

$$
\begin{gathered}
E_{d e n}=\frac{C_{s} V}{2} \\
P_{d e s}=\frac{V^{2}}{4 m(E S R)}
\end{gathered}
$$

In the present study, the applied voltage $(\mathrm{V})$ on the cell assembled system of the EDLC was $0.9 \mathrm{~V}$. Figure 8a,b show the estimated energy and power densities of the EDLC throughout the 100 cycles. The values of $E_{d e n}$ and $P_{d e n}$ at the 1 st cycle are $14.5 \mathrm{Wh} \mathrm{kg}^{-1}$ and $1100 \mathrm{~W} \mathrm{~kg}^{-1}$, respectively. The two parameters drop to $8.8 \mathrm{Wh} \mathrm{kg}^{-1}$ and $500 \mathrm{~W} \mathrm{~kg}^{-1}$ at the 30th cycle. It is also noticed that beyond the 30th cycle to the 100th cycle, the energy and power densities become almost constant at $8.1 \mathrm{Wh} \mathrm{kg}^{-1}$ and $444 \mathrm{~W} \mathrm{~kg}^{-1}$, respectively. In an earlier study [87], the EDLC containing CS:dextran: $\mathrm{NH}_{4} \mathrm{~F}$ as an electrolyte that separates the electrodes has shown $1.4 \mathrm{Wh} \mathrm{kg}^{-1}$ and $428 \mathrm{~W} \mathrm{~kg}^{-1}$ values, respectively. It is well-defined that in the amorphous region, the conduction of ions is dominant [99]. The uniform values of energy density indicate that the ions in the plasticized electrolyte system face the same energy barrier during the conduction process of the interface [100]. Generally, the performance lowering of the EDLC-i.e., $C_{S}, E_{d e n}$, and $P_{d e n}$ values at higher cycles-is mainly due to electrolyte depletion. The depletion phenomenon occurs during the rapid charge-discharge process, where ion recombination results in aggregation. This also causes the potential energy developed at the surface of the carbon electrodes to be decreased [80].

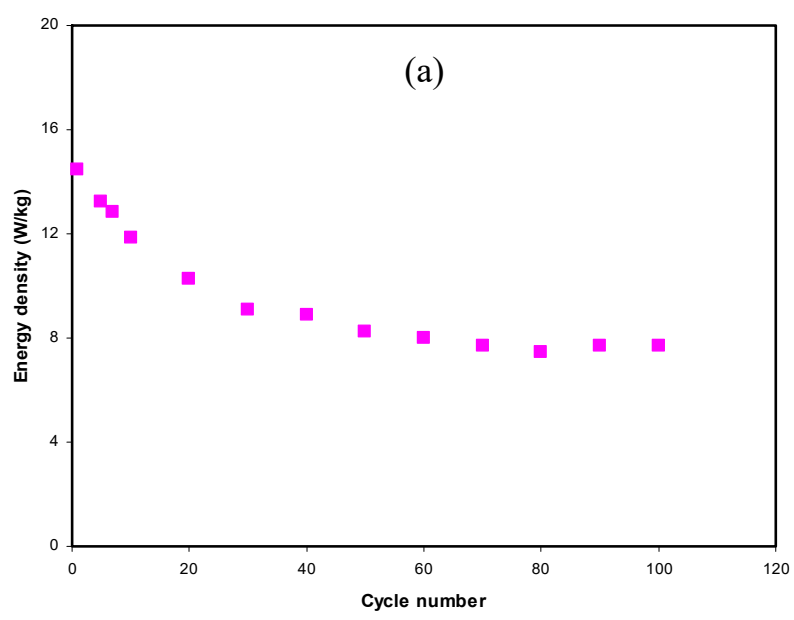

Figure 8. Cont. 


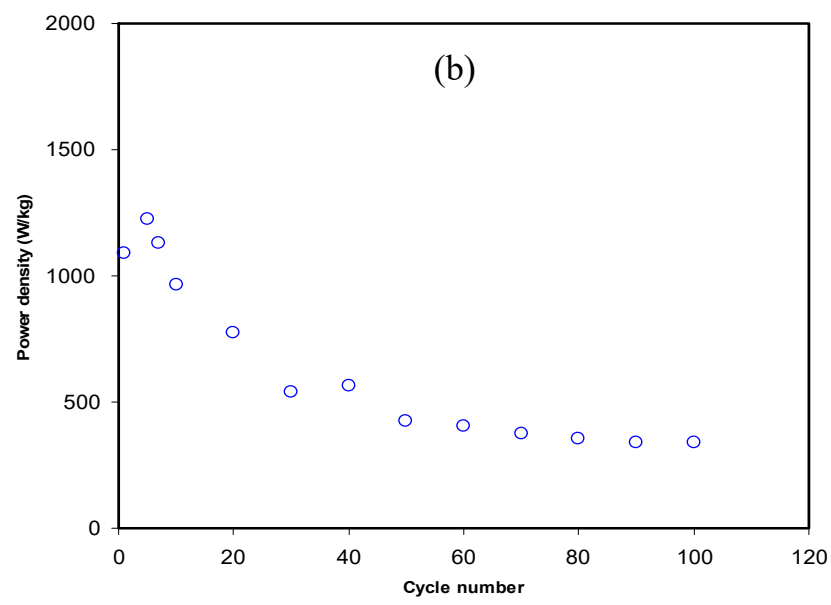

Figure 8. EDLC parameters of (a) energy density and (b) power density at $0.5 \mathrm{~mA} / \mathrm{cm}^{2}$ throughout the 100 cycles.

\section{Conclusions}

Preparation of lithium-based biopolymer electrolytes was carried out successfully using solution cast methodology. It is concluded that glycerol, as a plasticizer, improves the conductivity of polymer electrolyte considerably. The equivalent electric circuit (EEC) modeling helps us to rationalize the electrical character of the films. The sample doped with $42 \mathrm{wt} \%$ of glycerol shows the highest dielectric constant with the maximum ionic conductivity of $8.457 \times 10^{-4} \mathrm{~S} / \mathrm{cm}$. As the concentration of glycerol increased, the mobility $(\mu)$, diffusion coefficient $(D)$, and number density $(n)$ of ions gradually increased. A strong correlation between dielectric parameter and DC conductivity has been established and verified to comprehend the charge transport mechanism within the polymer electrolyte system. The TNM analysis confirmed that the primary charge carriers were ions. $t_{i o n}$ and $t_{e}$ values were identified to be 0.989 and 0.011 , respectively, for the highest conducting plasticized film. The LSV analysis showed that the decomposition voltage of the PVCSG3 system is $1.94 \mathrm{~V}$, indicating the electrolyte suitability for the EDLC application. Ultimately, the blending methodology has provided the desired polymer electrolyte with high ionic conductivity and good electrochemical properties. At the first cycle, the internal resistance, specific capacitance, energy density, and power density were determined to be $80 \Omega, 130 \mathrm{~F} / \mathrm{g}$, $14.5 \mathrm{Wh} / \mathrm{kg}$, and $1100 \mathrm{~W} / \mathrm{kg}$, respectively.

Author Contributions: Conceptualization, S.B.A., S.R.S., S.R.M. and M.F.Z.K.; Investigation, M.A.B. and M.H.H.; Methodology, M.A.B. and M.H.H.; Project administration, S.B.A., S.R.M., and M.F.Z.K.; Supervision, S.B.A.; Validation, S.R.S., R.T.A., and R.M.A.; Writing-original draft, M.A.B. and S.B.A.; Writing-review and editing, S.R.S., M.H.H., S.R.M., R.T.A., M.F.Z.K., and R.M.A. All authors have read and agreed to the published version of the manuscript.

Funding: This research received no external funding.

Acknowledgments: The authors appreciatively acknowledge all the support for finalizing this work by the University of Sulaimani, University of Malaya and Komar University of Science and Technology.

Conflicts of Interest: The authors declare no conflict of interest.

\section{References}

1. Aziz, B.; Kadir, M.F.Z.; Abidin, Z.H.Z. Structural, morphological and electrochemical impedance study of CS:LiTf based solid polymer electrolyte: Reformulated Arrhenius equation for ion transport study. Int. J. Electrochem. Sci. 2016, 11, 9228-9244. [CrossRef]

2. Verma, M.L.; Minakshi, M.; Singh, N.K. Structural and electrochemical properties of nanocomposite polymer electrolyte for electrochemical devices. Ind. Eng. Chem. Res. 2014, 53, 14993-15001. [CrossRef]

3. De Leeuw, S.; Van Zon, A.; Bel, G. Structural relaxation in poly(ethyleneoxide) and poly(ethyleneoxide)-sodium iodide systems: A molecular dynamics study. Electrochim. Acta 2001, 46, 1419-1426. [CrossRef] 
4. Aziz, S.B. Li+ ion conduction mechanism in poly ( $\varepsilon$-caprolactone)-based polymer electrolyte. Iran. Polym. J. 2013, 22, 877-883. [CrossRef]

5. Mason, R.N.; Hu, L.; Glatzhofer, D.T.; Frech, R. Infrared spectroscopic and conductivity studies of poly(N-methylpropylenimine)/lithium triflate electrolytes. Solid State Ion. 2010, 180, 1626-1632. [CrossRef]

6. Aziz, S.B.; Abidin, Z.; Arof, A. Effect of silver nanoparticles on the DC conductivity in chitosan-silver triflate polymer electrolyte. Phys. B Condens. Matter 2010, 405, 4429-4433. [CrossRef]

7. Zhou, S.; Fang, S. High ionic conductivity of all-solid polymer electrolytes based on polyorganophosphazenes. Eur. Polym. J. 2007, 43, 3695-3700. [CrossRef]

8. Wang, Y.; Song, S.; Xu, C.; Hu, N.; Molenda, J.; Lu, L. Development of solid-state electrolytes for sodium-ion battery-A short review. Nano Mater. Sci. 2019, 1, 91-100. [CrossRef]

9. Aziz, S.B.; Hamsan, M.H.; Abdullah, R.M.; Kadir, M.F.Z. A promising polymer blend electrolytes based on chitosan: Methyl cellulose for EDLC application with high specific capacitance and energy density. Molecules 2019, 24, 2503. [CrossRef]

10. Aziz, S.B.; Abdulwahid, R.T.; Hamsan, M.H.; Brza, M.A.; Abdullah, R.M.; Kadir, M.F.Z.; Muzakir, S.K. Structural, impedance, and EDLC characteristics of proton conducting chitosan-based polymer blend electrolytes with high electrochemical stability. Molecules 2019, 24, 3508. [CrossRef]

11. Salleh, N.S.; Aziz, S.B.; Aspanut, Z.; Kadir, M.F.Z. Electrical impedance and conduction mechanism analysis of biopolymer electrolytes based on methyl cellulose doped with ammonium iodide. Ionics 2016, 22, 2157-2167. [CrossRef]

12. Aziz, S.B.; Hamsan, M.H.; Kadir, M.F.Z.; Karim, W.O.; Abdullah, R.M. Development of polymer blend electrolyte membranes based on chitosan: Dextran with high ion transport properties for EDLC application. Int. J. Mol. Sci. 2019, 20, 3369. [CrossRef] [PubMed]

13. Dannoun, E.M.; Aziz, S.B.; Brza, M.A.; Nofal, M.M.; Asnawi, A.S.; Yusof, Y.M.; Al-Zangana, S.; Hamsan, M.H.; Kadir, M.F.Z.; Woo, H.J. The study of plasticized solid polymer blend electrolytes based on natural polymers and their application for energy storage EDLC devices. Polymers 2020, 12, 2531. [CrossRef] [PubMed]

14. Aziz, B.S.; Hamsan, M.H.; Nofal, M.M.; Karim, W.O.; Brevik, I.; Brza, M.; Abdulwahid, R.T.; Al-Zangana, S.; Kadir, M.F. Structural, impedance and electrochemical characteristics of electrical double layer capacitor devices based on chitosan: Dextran biopolymer blend electrolytes. Polymers 2020, 12, 1411. [CrossRef]

15. Hirase, R.; Higashiyama, Y.; Mori, M.; Takahara, Y.; Yamane, C. Hydrated salts as both solvent and plasticizer for chitosan. Carbohydr. Polym. 2010, 80, 993-996. [CrossRef]

16. Asnawi, A.S.; Aziz, S.B.; Nofal, M.M.; Hamsan, M.H.; Brza, M.A.; Yusof, Y.M.; Abdulwahid, R.T.; Muzakir, S.K.; Kadir, M.F.Z. Glycerolized $\mathrm{Li}^{+}$ion conducting chitosan-based polymer electrolyte for energy storage EDLC device applications with relatively high energy density. Polymers 2020, 12, 1433. [CrossRef]

17. Trung, T.S.; Thein-Han, W.W.; Qui, N.T.; Ng, C.-H.; Stevens, W.F. Functional characteristics of shrimp chitosan and its membranes as affected by the degree of deacetylation. Bioresour. Technol. 2006, 97, 659-663. [CrossRef]

18. Marif, A.S.; Abdullah, R.M.; Aziz, S.B. Structural, morphological, electrical and electrochemical properties of PVA: CS-Based proton-conducting polymer blend electrolytes. Membranes 2020, 10, 71. [CrossRef]

19. Aziz, S.B.; Abidin, Z.Z.; Kadir, M.F.Z. Innovative method to avoid the reduction of silver ions to silver nanoparticles in silver ion conducting based polymer electrolytes. Phys. Scr. 2015, 90, 035808. [CrossRef]

20. Cheng, M.; Deng, J.; Yang, F.; Gong, Y.; Zhao, N.; Zhang, X. Study on physical properties and nerve cell affinity of composite films from chitosan and gelatin solutions. Biomaterials 2003, 24, 2871-2880. [CrossRef]

21. Yang, J.M.; Chiu, H.C. Preparation and characterization of polyvinyl alcohol/chitosan blended membrane for alkaline direct methanol fuel cells. J. Membr. Sci. 2012, 65-71, 419-420.

22. Yang, C.C. Polymer Ni-MH battery based on PEO-PVA-KOH polymer electrolyte. J. Power Sources 2002, 109, 22-31. [CrossRef]

23. Yang, C.C.; Lin, S.J. Alkaline composite PEO-PVA-glass-fiber-mat polymer electrolyte for Zn-air battery. J. Power Sources 2002, 112, 497-503. [CrossRef]

24. Aziz, S.B.; Brza, M.A.; Hamsan, M.H.; Kadir, M.F.Z.; Muzakir, S.K.; Abdulwahid, R.T. Effect of ohmic-drop on electrochemical performance of EDLC fabricated from PVA:dextran:NH4I based polymer blend electrolytes. J. Mater. Res. Technol. 2020, 9, 3734-3745. [CrossRef]

25. Aziz, S.B. Modifying poly (vinyl alcohol)(PVA) from insulator to small-bandgap polymer: A novel approach for organic solar cells and optoelectronic devices. J. Electron. Mater. 2016, 45, 736-745. [CrossRef] 
26. Aziz, S.B.; Brza, M.A.; Hamsan, H.M.; Kadir, M.F.Z.; Abdulwahid, R.T. Electrochemical characteristics of solid state double-layer capacitor constructed from proton conducting chitosan-based polymer blend electrolytes. Polym. Bull. 2020. [CrossRef]

27. Kadir, M.; Aspanut, Z.; Majid, S.; Arof, A. FTIR studies of plasticized poly(vinyl alcohol-chitosan blend doped with $\mathrm{NH}_{4} \mathrm{NO}_{3}$ polymer electrolyte membrane. Spectrochim. Acta Part. A Mol. Biomol. Spectrosc. 2011, 78, 1068-1074. [CrossRef]

28. Aziz, S.B.; Kadir, M.F.Z.; Hamsan, M.H.; Woo, H.J.; Brza, M.A. Development of polymer blends based on PVA:POZ with low dielectric constant for microelectronic applications. Sci. Rep. 2019, 9, 1-12. [CrossRef]

29. Sudhakar, Y.N.; Selvakumar, M.; Bhat, D.K. $\mathrm{LiClO}_{4}$-doped plasticized chitosan and poly (ethylene glycol) blend as biodegradable polymer electrolyte for supercapacitors. Ionics 2013, 19, 277-285. [CrossRef]

30. Aziz, S.B.; Marif, R.B.; Brza, M.A.; Hamsan, M.H.; Kadir, M.F.Z. Employing of Trukhan model to estimate ion transport parameters in PVA based solid polymer electrolyte. Polymers 2019, 11, 1694. [CrossRef]

31. Brza, M.; Aziz, S.B.; Anuar, H.; Ali, F.; Hamsan, M.; Kadir, M.; Abdulwahid, R.T. Metal framework as a novel approach for the fabrication of electric double layer capacitor device with high energy density using plasticized Poly(vinyl alcohol): Ammonium thiocyanate based polymer electrolyte. Arab. J. Chem. 2020, 13, 7247-7263. [CrossRef]

32. Aziz, S.B.; Abidin, Z.H.Z. Ion-transport study in nanocomposite solid polymer electrolytes based on chitosan: Electrical and dielectric analysis. J. Appl. Polym. Sci. 2015, 132, 41774. [CrossRef]

33. Aziz, S.B. Role of dielectric constant on Ion transport: Reformulated Arrhenius equation. Adv. Mater. Sci. Eng. 2016, 2016, 2527013. [CrossRef]

34. Aziz, S.B.; Abidin, Z.H.Z. Electrical and morphological analysis of chitosan: AgTf solid electrolyte. Mater. Chem. Phys. 2014, 144, 280-286. [CrossRef]

35. Pradhan, D.K.; Choudhary, R.N.P.; Samantaray, B.K. Studies of dielectric relaxation and AC conductivity behavior of plasticized polymer nanocomposite electrolytes. Int. J. Electrochem. Sci. 2008, 3, 597-608.

36. Yeow, M.L.; Liu, Y.; Li, K. Preparation of porous PVDF hollow fiber membrane via a phase inversion method using lithium perchlorate ( $\mathrm{LiClO} 4)$ as an additive. J. Membr. Sci. 2005, 258, 16-22. [CrossRef]

37. Teoh, K.H.; Ramesh, S.; Arof, A.K. Investigation on the effect of nanosilica towards corn starch-lithium perchlorate-based polymer electrolytes. J. Solid State Electrochem. 2012, 16, 3165-3170. [CrossRef]

38. Pawlicka, A.; Danczuk, M.; Wieczorek, W.; Zygadło-Monikowska, E. Influence of plasticizer type on the properties of polymer electrolytes based on chitosan. J. Phys. Chem. A 2008, 112, 8888-8895. [CrossRef]

39. Shukur, M.F.; Yusof, Y.M.; Zawawi, S.M.M.; A Illias, H.; Kadir, M.F.Z. Conductivity and transport studies of plasticized chitosan-based proton conducting biopolymer electrolytes. Phys. Scr. 2013, 157, 014050-014055. [CrossRef]

40. Cevik, E.; Gunday, S.T.; Bozkurt, A.; Amine, R.; Amine, K. Bio-inspired redox mediated electrolyte for high performance flexible supercapacitor applications over broad temperature domain. J. Power Sources 2020, 474, 228544. [CrossRef]

41. Shar, S.S.; Çevik, E.; Bozkurt, A.; Yaman, C.; AlMutari, Z.; Kayed, T.S. Molybdate incorporated poly(acrylic acid) electrolytes for use in quasi-solid state carbon based supercapacitors: Redox-active polychelates. Electrochim. Acta 2020, 354, 136770. [CrossRef]

42. Çevik, E.; Bozkurt, A. Redox active polymer metal chelates for use in flexible symmetrical supercapacitors: Cobalt-containing poly(acrylic acid) polymer electrolytes. J. Energy Chem. 2020, 55, 145-153. [CrossRef]

43. Aziz, S.B.; Woo, T.J.; Kadir, M.; Ahmed, H.M. A conceptual review on polymer electrolytes and ion transport models. J. Sci. Adv. Mater. Devices 2018, 3, 1-17. [CrossRef]

44. Aziz, S.B.; Abdullah, R.M.; Kadir, M.F.Z.; Ahmed, H.M. Non suitability of silver ion conducting polymer electrolytes based on chitosan mediated by barium titanate $\left(\mathrm{BaTiO}_{3}\right)$ for electrochemical device applications. Electrochim. Acta 2019, 296, 494-507. [CrossRef]

45. Aziz, S.B.; Brza, M.A.; Mohamed, P.A.; Kadir, M.F.Z.; Hamsan, M.H.; Abdulwahid, R.T.; Woo, H.J. Increase of metallic silver nanoparticles in Chitosan: AgNt based polymer electrolytes incorporated with alumina filler. Results Phys. 2019, 13, 102326. [CrossRef]

46. Pradhan, D.K.; Choudhary, R.N.P.; Samantaray, B.K.; Karan, N.K.; Katiyar, R.S. Effect of plasticizer on structural and electrical properties of polymer nanocompsoite electrolytes. Int. J. Electrochem. Sci. 2007, 2, 861-871. 
47. Aziz, S.B.; Karim, W.O.; Qadir, K.; Zafar, Q. Proton ion conducting solid polymer electrolytes based on chitosan incorporated with various amounts of barium titanate (BaTiO3). Int. J. Electrochem. Sci. 2018, 13, 6112-6125. [CrossRef]

48. Brza, M.; Aziz, S.; Anuar, H.; Ali, F. Structural, ion transport parameter and electrochemical properties of plasticized polymer composite electrolyte based on PVA: A novel approach to fabricate high performance EDLC devices. Polym. Test. 2020, 91, 106813. [CrossRef]

49. Shukur, M.F.; Ithnin, R.; Kadir, M.F.Z. Electrical characterization of corn starch-LiOAc electrolytes and application in electrochemical double layer capacitor. Electrochim. Acta 2014, 136, 204-216. [CrossRef]

50. Mertens, I.J.A.; Wubbenhorst, M.; Oosterbaan, W.D.; Jenneskens, L.W.; van Turnhout, J. Novel polymer electrolytes based on amorphous poly(etherester)s containing 1,4,7-trioxanonyl main chain units. Ionic conductivity versus polymer chain mobility. Macromolecules 1999, 32, 3314-3324. [CrossRef]

51. Aziz, S.B.; Hamsan, M.H.; Karim, W.O.; Marif, A.S.; Abdulwahid, R.T.; Kadir, M.F.Z.; Brza, M.A. Study of impedance and solid-state double-layer capacitor behavior of proton $(\mathrm{H}+)$-conducting polymer blend electrolyte-based CS:PS polymers. Ionics 2020, 26, 4635-4649. [CrossRef]

52. Aziz, S.B.; Hamsan, M.H.; Abdullah, R.M.; Abdulwahid, R.T.; Brza, M.A.; Marif, A.S.; Kadir, M.F.Z. Protonic EDLC cell based on chitosan (CS): Methylcellulose (MC) solid polymer blend electrolytes. Ionics 2020, 26, 1829-1840. [CrossRef]

53. Aziz, S.B.; Brevik, I.; Hamsan, M.H.; Brza, M.A.; Nofal, M.M.; Abdullah, A.M.; Rostam, S.; Al-Zangana, S.; Muzakir, S.K.; Kadir, M.F.Z. Compatible solid polymer electrolyte based on methyl cellulose for energy storage application: Structural, electrical, and electrochemical properties. Polymers 2020, 12, 2257. [CrossRef]

54. Arof, A.K.; Amirudin, S.; Yusof, S.Z.; Noor, I. A method based on impedance spectroscopy to determine transport properties of polymer electrolytes. Phys. Chem. Chem. Phys. 2014, 16, 1856-1867. [CrossRef]

55. Yusof, Y.M.; Shukur, M.F.; Hamsan, M.H.; Jumbri, K.; Kadir, M.F.Z. Plasticized solid polymer electrolyte based on natural polymer blend incorporated with lithium perchlorate for electrical double-layer capacitor fabrication. Ionics 2019, 25, 5473-5484. [CrossRef]

56. Shamsuddin, L.; Noor, I.; Albinsson, I.; Mellander, B.E.; Arof, A.K. Perovskite solar cells using polymer electrolytes. Mol. Cryst. Liq. Cryst. 2017, 655, 181-194. [CrossRef]

57. Okutan, M.; Senturk, E. $\beta$ dielectric relaxation mode in side-chain liquid crystalline polymer film. J. Non-Cryst. Solids 2008, 357, 1526-1530. [CrossRef]

58. Hamsan, M.H.; Shukur, M.F.; Aziz, S.B.; Kadir, M.F.Z. Dextran from Leuconostoc mesenteroides-doped ammonium salt-based green polymer electrolyte. Bull. Mater. Sci. 2019, 42, 57. [CrossRef]

59. Batoo, K.M.; Kumar, S.; Lee, C.G.; Alimuddin. Study of dielectric and ac impedance properties of Ti doped Mn ferrites. Curr. Appl. Phys. 2009, 9, 1397-1406. [CrossRef]

60. Aziz, S.B.; Brza, M.; Saed, S.R.; Hamsan, M.; Kadir, M. Ion association as a main shortcoming in polymer blend electrolytes based on CS:PS incorporated with various amounts of ammonium tetrafluoroborate. J. Mater. Res. Technol. 2020, 9, 5410-5421. [CrossRef]

61. Pradhan, D.K.; Choudhary, R.N.P.; Samantaray, B.K. Studies of structural, thermal and electrical behavior of polymer nanocomposite electrolytes. eXPRESS Polym. Lett. 2008, 2, 630-638. [CrossRef]

62. Karim, W.O.; Ghareeb, H.O. The deficiency of chitosan: AgNO3 polymer electrolyte incorporated with titanium dioxide filler for device fabrication and membrane separation technology. J. Mater. Res. Technol. 2020, 9, 4692-4705.

63. Marf, A.S.; Aziz, S.B.; Abdullah, R.M. Plasticized H+ ion-conducting PVA:CS-based polymer blend electrolytes for energy storage EDLC application. J. Mater. Sci. Mater. Electron. 2020. [CrossRef]

64. Aziz, S.B.; Brza, M.A.; Brevik, I.; Hamsan, M.H.; Asnawi, A.S.; Yusof, Y.M.; Abdulwahid, R.T.; Kadir, M.F.Z. Blending and characteristics of electrochemical double-layer capacitor device assembled from plasticized proton ion conducting chitosan:dextran: $\mathrm{NH}_{4} \mathrm{PF}_{6}$ polymer electrolytes. Polymers 2020, 12, 2103. [CrossRef]

65. Tripathi, M.; Tripathi, S. Electrical studies on ionic liquid-based gel polymer electrolyte for its application in EDLCs. Ionics 2017, 23, 2735-2746. [CrossRef]

66. Hamsan, M.; Aziz, S.B.; Kadir, M.; Brza, M.; Karim, W.O. The study of EDLC device fabricated from plasticized magnesium ion conducting chitosan based polymer electrolyte. Polym. Test. 2020, 90, 106714. [CrossRef] 
67. Kufian, M.; Aziz, M.; Shukur, M.; Rahim, A.; Ariffin, N.; Shuhaimi, N.; Majid, S.; Yahya, R.; Arof, A.K. PMMA-LiBOB gel electrolyte for application in lithium ion batteries. Solid State Ion. 2012, 208, 36-42. [CrossRef]

68. Diederichsen, K.M.; McShane, E.J.; McCloskey, B.D. Promising routes to a high Li+ transference number electrolyte for lithium ion batteries. ACS Energy Lett. 2017, 2, 2563-2575. [CrossRef]

69. Aziz, S.B.; Hadi, J.M.; Hamsan, E.M.A.D.M.H.; Abdulwahid, R.T.; Saeed, S.R.; Marif, A.S.; Karim, W.O.; Kadir, M.F.Z. The study of plasticized amorphous biopolymer blend electrolytes based on polyvinyl alcohol (PVA): Chitosan with high ion conductivity for energy storage electrical double-layer capacitors (EDLC) device application. Polymers 2020, 12, 1938. [CrossRef]

70. Aziz, S.B.; Hamsan, M.H.; Brza, M.A.; Kadir, M.F.Z.; Muzakir, S.K.; Abdulwahid, R.T. Effect of glycerol on EDLC characteristics of chitosan:methylcellulose polymer blend electrolytes. J. Mater. Res. Technol. 2020, 9 , 8355-8366. [CrossRef]

71. Pande, G.P.; Kumar, Y.; Hashmi, S.A. Ionic liquid incorporated polymer electrolytes for supercapacitor application. Indian J. Chem. 2010, 49A, 743-751.

72. Hadi, J.M.; Aziz, S.B.; Nofal, M.M.; Hussein, S.A.; Hamsan, M.H.; Brza, M.A.; Abdulwahid, R.T.; Kadir, M.F.Z.; Woo, H.J. Electrical, dielectric property and electrochemical performances of plasticized silver ion-conducting chitosan-based polymer nanocomposites. Membranes 2020, 10, 151. [CrossRef] [PubMed]

73. Sampathkumar, L.; Selvin, P.C.; Selvasekarapandian, S.; Perumal, P.; Chitra, R.; Muthukrishnan, M. Synthesis and characterization of biopolymer electrolyte based on tamarind seed polysaccharide, lithium perchlorate and ethylene carbonate for electrochemical applications. Ionics 2019, 25, 1067-1082. [CrossRef]

74. Monisha, S.; Mathavan, T.; Selvasekarapandian, S.; Benial, A.M.F.; Latha, M.P. Preparation and characterization of cellulose acetate and lithium nitrate for advanced electrochemical devices. Ionics 2016, 23, 2697-2706. [CrossRef]

75. Böckenfeld, N.; Willeke, M.; Pires, J.; Anouti, M.; Balducci, A. On the use of lithium iron phosphate in combination with protic ionic liquid-based electrolytes. J. Electrochem. Soc. 2013, 160, A559-A563. [CrossRef]

76. Moniha, V.; Alagar, M.; Selvasekarapandian, S.; Sundaresan, B.; Hemalatha, R.; Boopathi, G. Synthesis and characterization of bio-polymer electrolyte based on iota-carrageenan with ammonium thiocyanate and its applications. J. Solid State Electrochem. 2018, 22, 3209-3223. [CrossRef]

77. Pandey, G.; Kumar, Y.; Hashmi, S.A. Ionic liquid incorporated PEO based polymer electrolyte for electrical double layer capacitors: A comparative study with lithium and magnesium systems. Solid State Ion. 2011, 190, 93-98. [CrossRef]

78. Sundaram, M.M.; Appadoo, D. Traditional salt-in-water electrolyte vs. water-in-salt electrolyte with binary metal oxide for symmetric supercapacitors: Capacitive vs. faradaic. Dalton Trans. 2020, 49, 11743-11755. [CrossRef]

79. Biswal, A.; Panda, P.K.; Acharya, A.N.; Tripathy, B.C.; Alenazey, F.S.; Jiang, Z.-T.; Sundaram, M.M. Tuning the morphology and redox behaviour by varying the concentration of $\mathrm{Fe}$ in a CoNiFe ternary oxide heterostructure for hybrid devices. N. J. Chem. 2020, 44, 9921-9932. [CrossRef]

80. Liew, C.-W.; Ramesh, S. Electrical, structural, thermal and electrochemical properties of corn starch-based biopolymer electrolytes. Carbohydr. Polym. 2015, 124, 222-228. [CrossRef]

81. Hashmi, S.A.; Latham, R.J.; Linford, R.G.; Schlindwein, W.S. Polymer electrolyte based solid state redox supercapacitors with poly (3-methyl thiophene) and polypyrrole conducting polymer electrodes. Ionics 1997, 3, 177-183. [CrossRef]

82. Winie, T.; Jamal, A.; Saaid, F.I.; Tseng, T.-Y. Hexanoyl chitosan/ENR25 blend polymer electrolyte system for electrical double layer capacitor. Polym. Adv. Technol. 2018, 30, 726-735. [CrossRef]

83. Pandey, G.P.; Hashmi, S.A.; Kumar, Y. Multiwalled carbon nanotube electrodes for electrical double layer capacitors with ionic liquid based gel polymer electrolytes. J. Electrochem. Soc. 2010, 157, A105-A114. [CrossRef]

84. Hamsan, M.H.; Aziz, S.B.; Azha, M.A.S.; Azli, A.A.; Shukur, M.F.; Yusof, Y.M.; Muzakir, S.K.; Manan, N.S.A.; Kadir, M.F.Z. Solid-state double layer capacitors and protonic cell fabricated with dextran from Leuconostocmesenteroides based green polymer electrolyte. Mater. Chem. Phys. 2020, 241, 122290. [CrossRef]

85. Lim, C.-S.; Teoh, K.H.; Liew, C.-W.; Ramesh, S. Electric double layer capacitor based on activated carbon electrode and biodegradable composite polymer electrolyte. Ionics 2014, 20, 251-258. [CrossRef] 
86. Aziz, S.B.; Brevik, I.; Brza, M.A.; Asnawi, A.S.F.M.; Dannoun, E.M.A.; Yusof, Y.M.; Abdulwahid, R.T.; Hamsan, M.H.; Nofal, M.M.; Kadir, M.F.Z. The study of structural, impedance and energy storage behavior of plasticized PVA:MC based proton conducting polymer blend electrolytes. Materials 2020, 13, 5030. [CrossRef]

87. Aziz, S.B.; Hamsan, M.H.; Brza, M.A.; Kadir, M.F.Z.; Abdulwahid, R.T.; Ghareeb, H.O.; Woo, H.J. Fabrication of energy storage EDLC device based on CS:PEO polymer blend electrolytes with high Li+ ion transference number. Results Phys. 2019, 15, 102584. [CrossRef]

88. Teoh, K.H.; Lim, C.-S.; Liew, C.-W.; Ramesh, S. Electric double-layer capacitors with corn starch-based biopolymer electrolytes incorporating silica as filler. Ionics 2015, 21, 2061-2068. [CrossRef]

89. Boonen, L.; Kitzler, P.; Kasum, J. Processing of aqueous polymer electrolytes for supercapacitors via different industrial application methods. Prog. Org. Coat. 2018, 115, 107-114. [CrossRef]

90. Łatoszyńska, A.A.; Taberna, P.-L.; Simon, P.; Wieczorek, W. Proton conducting gel polymer electrolytes for supercapacitor applications. Electrochim. Acta 2017, 242, 31-37. [CrossRef]

91. Fattah, N.F.A.; Wang, H.M.-L.; Mahipal, Y.K.; Numan, A.; Ramesh, S.; Ramesh, K. An approach to solid-state electrical double layer capacitors fabricated with graphene oxide-doped, ionic liquid-based solid copolymer electrolytes. Materials 2016, 9, 450. [CrossRef] [PubMed]

92. Härmas, R.; Palm, R.; Härmas, M.; Pohl, M.; Kurig, H.; Tallo, I.; Tee, E.; Vaas, I.; Väli, R.; Romann, T.; et al. Influence of porosity parameters and electrolyte chemical composition on the power densities of non-aqueous and ionic liquid based supercapacitors. Electrochim. Acta 2018, 283, 931-948. [CrossRef]

93. Zhao, W.; Kido, G.; Hara, K.; Noguchi, H. Characterization of neutralized graphite oxide and its use in electric double layer capacitors. J. Electroanal. Chem. 2014, 712, 185-193. [CrossRef]

94. Minakshi, M. Lithium intercalation into amorphous FePO4 cathode in aqueous solutions. Electrochim. Acta 2010, 55, 9174-9178. [CrossRef]

95. Minakshi, M.; Singh, P.; Sharma, N.; Blackford, M.; Ionescu, M. Lithium extraction-insertion from/into LiCoPO4 in aqueous batteries. Ind. Eng. Chem. Res. 2011, 50, 1899-1905. [CrossRef]

96. Arof, A.K.; Kufian, M.Z.; Syukur, M.F.; Aziz, M.F.; Abdelrahman, A.E.; Majid, S.R. Electrical double layer capacitor using poly(methyl methacrylate)-C4BO8Li gel polymer electrolyte and carbonaceous material from shells of mata kucing (Dimocarpus longan) fruit. Electrochim. Acta 2012, 74, 39-45. [CrossRef]

97. Asmara, S.N.; Kufian, M.Z.; Majid, S.R.; Arof, A.K. Preparation and characterization of magnesium ion gel polymer electrolytes for application in electrical double layer capacitors. Electrochim. Acta 2011, 57, 91-97. [CrossRef]

98. Yang, H.; Kannappan, S.; Pandian, A.S.; Jang, J.-H.; Lee, Y.S.; Lu, W. Graphene supercapacitor with both high power and energy density. Nanotechnology 2017, 28, 44. [CrossRef]

99. Pesko, D.M.; Jung, Y.; Hasan, A.L.; Webb, M.A.; Coates, G.W.; Miller, T.F.; Balsara, N.P. Effect of monomer structure on ionic conductivity in a systematic set of polyester electrolytes. Solid State Ion. 2016, 289, 118-124. [CrossRef]

100. Hamsan, M.H.; Shukur, M.F.; Kadir, M.F.Z. $\mathrm{NH}_{4} \mathrm{NO}_{3}$ as charge carrier contributor in glycerolized potato starch-methyl cellulose blend-based polymer electrolyte and the application in electrochemical double-layer capacitor. Ionics 2017, 23, 3429-3453. [CrossRef]

Publisher's Note: MDPI stays neutral with regard to jurisdictional claims in published maps and institutional affiliations.

(C) 2020 by the authors. Licensee MDPI, Basel, Switzerland. This article is an open access article distributed under the terms and conditions of the Creative Commons Attribution (CC BY) license (http://creativecommons.org/licenses/by/4.0/). 